\title{
SPECIFIC GAS PERMEABILITY OF NORMAL AND NANOSILVER-IMPREGNATED SOLID WOOD SPECIES AS INFLUENCED BY HEAT-TREATMENT
}

\author{
Hamid R. Taghiyari ${ }^{1, \star}$, Stavros Avramidis ${ }^{2}$
}

\begin{abstract}
The effect of heat treatment at 50 and up to $150^{\circ} \mathrm{C}$ was studied on dowel-shape specimens prepared from beech (Fagus orientalis), poplar (Populus nigra), and fir (Abies alba) wood. Specimens were cut into two diameter sizes $(18$ and $25 \mathrm{~mm}$ ) to explore the effect of diameter size on permeability. Separate sets of specimens from each size and species were prepared to be first impregnated with a $200 \mathrm{ppm}$ aqueous nanosilver (NS) suspension to investigate the effect of facilitated heat-transfer on permeability at different temperatures. Specimens were heated in five consecutive steps at 50,75, 100, 125 , and $150^{\circ} \mathrm{C}$ and for 24 hours in each step. High variance was found in the specific gas permeability between each treatment group, thus indicating probable high fluctuation in settlement of extractives at different spots of a log. Heat treatment only affected gas permeability at the first steps of heating ( 50 and $75^{\circ} \mathrm{C}$ ), where loss of moisture content resulted in a permeability increase in nearly all species. Consecutive steps of heating up to $150^{\circ} \mathrm{C}$ did not significantly affect the permeability in either normal or NS-impregnated specimens.
\end{abstract}

Keywords: Beech, poplar, fir, longitudinal permeability, wood-modification.

\section{INTRODUCTION}

Wood is a unique material that has helped humans over centuries develop their culture, civilization, and community. However, there are some inherent drawbacks such as dimensional instability, biological degradation, and combustion, to name a few; moreover, the natural regeneration of trees may not cover the increasing needs for wood. Therefore, it is frequently modified by engineering processes to gain stiffness or more homogeneous physical and mechanical properties (Papadopoulos 2012). Heat treatment (thermal modification) of wood is generally considered the most commercially used engineering process (Hill 2006). Effect of heat treatment from various perspective is quite elaborated during the past decades (Ayata et al. 2017, Salman et al. 2017). However, little research has been done as to the effects of heat treatment on permeability as an important physical property in solid wood species (Poonia et al. 2016). Therefore, a primary objective of the present project was to find out the effects of heat treatment at different temperatures on gas permeability in some hardwood and softwood species. Over the past two decades, nano-materials have been used to improve quality in many materials, including wood and wood composites (Ismita and Lokesh 2017, Muñoz and Moya 2018). In this connection, low thermal conductivity coefficient of wood (Taghiyari et al. 2013) makes heat-treatment process rather lengthy, especially in those treatments where the medium is not water or vapor. Different metal and mineral nano-fluids with enhanced thermal conductivity coefficients and dispersed metallic nanoparticles (Majidi 2016, Matinise et al. 2016, Pethig 2017, Suganya et al.

\footnotetext{
${ }^{1}$ Department of Wood Science and Technology, Faculty of Materials Engineering \& New Technologies, Shahid Rajaee Teacher Training University, Lavizan, Tehran, Iran.

${ }^{2}$ Department of Wood Science, University of British Columbia, Vancouver, Canada. stavros.avramidis@ubc.ca

•Corresponding author: htaghiyari@yahoo.com \& htaghiyari@sru.ac.ir

Received: 21.10.2017 Accepted: 12.08.2018
} 
2017) were applied in wood and wood-composites with an aim to accelerate heat transfer to the inner parts of specimens in air medium (Ghorbani et al. 2012, Esmailpour et al. 2017). Therefore, as a secondary objective in the present research project, separate sets of specimens were prepared to be first impregnated with silver nano-suspension and to be heat-treated along with un-impregnated specimens. Comparison between the un-impregnated and nanosilver-impregnated specimens would eventually indicate if nanosilver would have any significant impact on gas permeability in different wood species, including hardwood and softwood species.

\section{MATERIALS AND METHODS}

\section{Specimen procurement and preparation}

Two commercial hardwoods and one softwood were chosen based on their importance in various industrial applications in Iran, namely, beech (Fagus orientalis), poplar (Populus nigra), and fir (Abies alba). Cylindrical specimens of $30 \mathrm{~mm}$ in length parallel to the tree main axes and of two diameters, specifically, 18 and $25 \mathrm{~mm}$ were cut from the mature wood area of beech and fir log sections, and from both mature and juvenile sections of poplar. All specimens were clear and free of any defects. A total of 20 specimens were produced ( 2 diameters $\times 10$ replicates) for each species which were randomly distributed into two groups, namely, nanosilver-impregnated (NSI) and control (C); totally, 80 specimens. The side-surface of each cylindrical specimen was covered by silicon adhesive to restrain air flow along the longitudinal axis. A separate set of specimens (40 specimens) were cut for mass-loss measurements. Mass-loss (ML) specimens were not covered with silicon adhesive.

\section{Gas permeability measurements}

Different methods have so far been used to determine permeability in wood and wood composites (Poonia et al. 2016). Longitudinal gas permeability measurements were carried out by an USPTOpatented apparatus equipped with an automatic-time-measurement device with millisecond precision (Taghiyari et al. 2012). The falling-water volume-displacement method was used to calculate specific longitudinal gas permeability values based on the microstructure porosity of wood (Avramidis and Mansfield 2005, Shi 2007).

Three measurements were taken for each specimen and the superficial permeability coefficient $\left(k_{g}\right)$ was then calculated using Equation 1 and Equation 2. The $k_{g}$ values were then multiplied by the viscosity of air $\left(\mu=1,81 \times 10^{-5} \mathrm{~Pa} \mathrm{~s}\right)$ for the calculation of the specific permeability $\left(K=k_{g} \mu\right)$ (Siau 1995).

\section{Nano-Silver (NS) impregnation process}

A $200 \mathrm{ppm}$ aqueous dispersion of silver nanoparticles was produced using an electrochemical technique. The size range of silver nanoparticles was $20-80 \mathrm{~nm}$ and the $\mathrm{pH}$ of the suspension was 6-7. Two kinds of surfactants (anionic and cationic) were used in the suspension as stabilizer and the concentration of the surfactants was three times the nano-silver particles. Empty-cell impregnation process (Rueping method) was carried out in a 3 bar pressure vessel by Mehrabadi IndustrialMachinery Mfg. Co. (Ltd.). After the impregnation process, all specimens were kept under ambient conditions for three months to dry so that the hygromechanical behavior of wood would not affect the permeability measurement (Figueroa et al. 2012). The $k_{g}$ of NSI specimens was re-measured before the heat-treatment process. 


\section{Heat-Treatment process}

All 80 specimens (C, NSI, and ML) were randomly arranged in a laboratory convection oven for the 24-hour thermal treatment that was carried out at consecutive steps of $50,75,100,125$, and $150^{\circ} \mathrm{C}$. After each step, specimens were carefully examined by a magnifying glass for possible macroscopic cracks; microscopic cracks caused by heat treatment are inevitable of solid wood (Hill 2006). After each of the above-mentioned heating steps, gas permeability of the specimen was measured after being cooled off on a bench top. Also, adhesive was checked after each step, and if necessary replaced after each step to make sure no air flow through lateral directions. ML specimens were weighed with a digital scale in the intervals to measure ML trend.

\section{Statistical analysis}

Statistical analysis was conducted using SAS software program, version 9.2 (2010). Two-way analysis of variance (ANOVA) was performed to discern significant difference at the $95 \%$ level of confidence. Grouping was then made between treatments using the Duncan's multiple range test. Regression and hierarchical cluster analysis, including dendrogram and using Ward methods with squared Euclidean distance intervals, was carried out by SPSS/18 (2010). Surface and contour plots were made by Minitab software, version 16.2.2 (2010).

\section{RESULTS AND DISCUSSION}

Specific gas permeability was significantly higher in poplar sapwood specimens in comparison to other treatments, including poplar heartwood (Figure 1). With regard to poplar heartwood, the higher permeability in poplar sapwood was attributed to lower extractive settlements in the cell and vessel cavities of sapwood poplar (Taghiyari et al. 2010), leaving them unobstructed for the passing of fluids. With regard to beech specimens, this was attributed to vessels with larger diameter as well as simple perforation of vessels in poplar wood. Fir specimens had the lowest permeability in comparison to other wood species. This low permeability was attributed to the small size of pit openings in tracheids of softwood species in comparison to the size of vessels in hardwood species. Any fluids should therefore make their way through small pit openings that connect adjacent tracheids.

Permeability measurement at the first step (ambient temperature) demonstrated that specimen size did not have any increasing or decreasing effect on specific gas permeability. Moreover, high withingroup variance was observed in specimens of the same treatment. It can therefore be concluded that in the studied solid wood species, concentration of extractives at scattered locations of wood would make permeability vary from one spot to the other. Moreover, extractive would be apt to settle down at points of constrict along the vessels in hardwoods (Imamura 1989, Taghiyari et al. 2010). However, measurement of the amount of extractives in each specimen should be carried out, and correlation between the permeability and extractive content of each single specimen be found, before making any firm and final conclusion in this regard. In order to test this hypothesis in a different way, specimens with both sizes were prepared from medium-density fiberboard (MDF) the permeability of which is not dependent on vessel, but its porous structure. Permeability values of MDF were 0,038 and 0,037 $\left(\times 10^{-13} \mathrm{~m}^{3} \mathrm{~m}^{-1}\right)$ for sizes 18 and $25 \mathrm{~mm}$, respectively. There was no statistical difference between the two values.

Impregnation with nanosilver suspension did not significantly change permeability values in any of the diameters and species. In most of the treatments, permeability increased at the first heating step $\left(50^{\circ} \mathrm{C}\right)$, where the highest weight losses occurred (Figure 2). This was attributed to the loss of a major part of moisture content, making vessels and pit openings unobstructed because of shrinkage, for the transfer of fluid. The highest increase in permeability were observed in beech specimens; this can be attributed to higher density of this species, making shrinkage higher than the other two species (poplar and fir). Permeability values showed no particular fluctuations in the further heating steps in most of the treatments. This indicated that thermal degradation up to $150^{\circ} \mathrm{C}$ do not have a significant impact on permeability. This was in agreement with the nearly constant weight loss values after the second heating step (Figure 2). Impregnation with nanosilver suspension only showed an increasing 
trend in beech specimens with $25 \mathrm{~mm}$ in diameter; other species and sizes demonstrated no significant difference in permeability between the normal and NS-impregnated specimens. It can therefore be concluded that the facilitated heat-transferring property in the NS-impregnated specimens are not so effective on permeability of small-sized specimens.
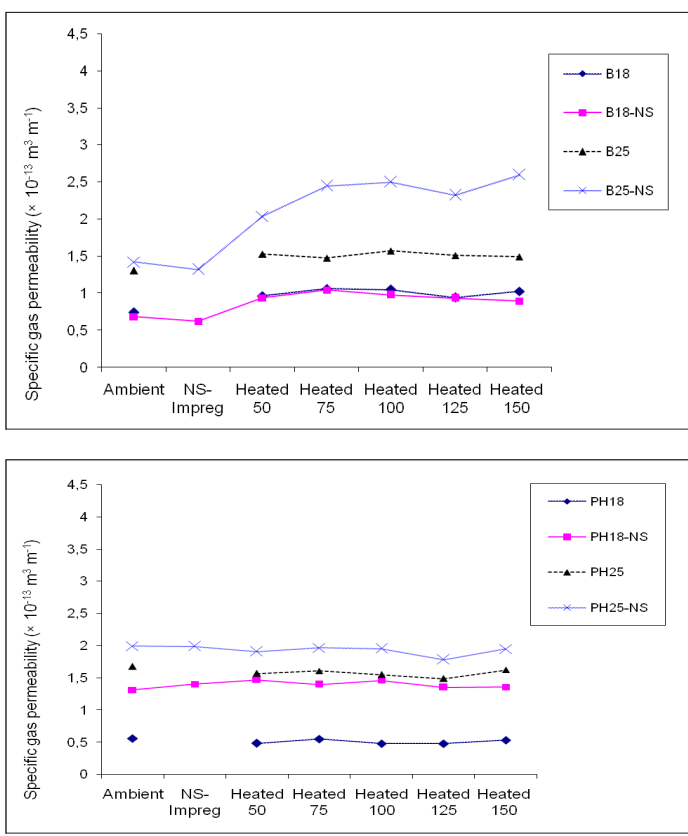

(b)
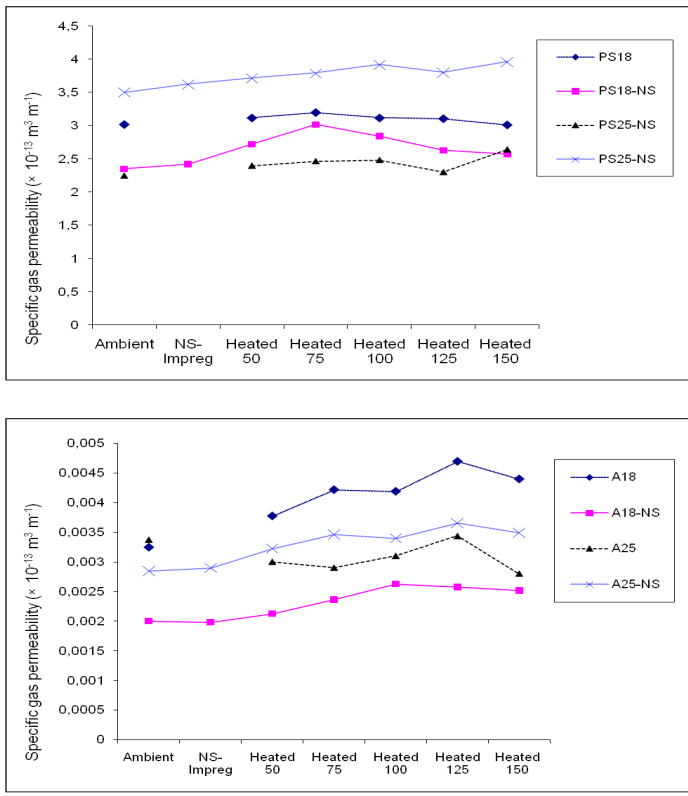

(d)

Figure 1: Specific gas permeability values in (a) beech, (b) poplar heartwood, (c) poplar sapwood, and (d) fir wood specimens for the two diameter groups.

(B=Beech; PH=Poplar heartwood; PS=Poplar sapwood; A=Abies fir wood; NS=Nanosilverimpregnated specimens $)\left(\times 10^{-13} \mathrm{~m}^{3} \mathrm{~m}^{-1}\right)$. 


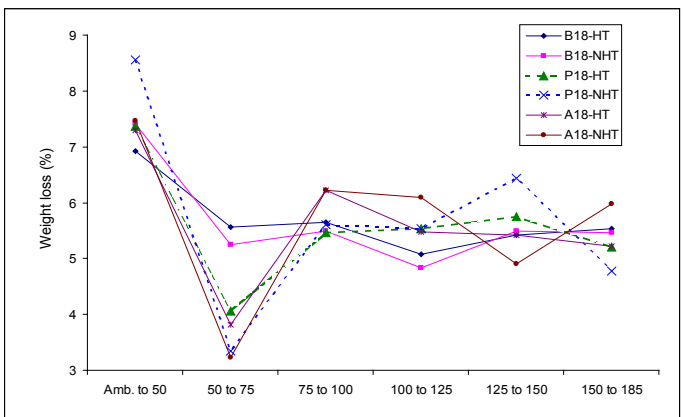

Figure 2: Weight losses (\%) caused by thermal treatment in poplar specimens at different stages of heat-treatment.

( $\mathrm{B}=$ beech; $\mathrm{HT}=$ heat-treated; $\mathrm{N}=$ nanosilver-impregnated; $\mathrm{P}=$ =poplar; $\mathrm{A}=\mathrm{Abies}$ ).

Regression analysis showed high significant R-square between nearly all gas permeability values measured when both the un-impregnated and nanosilver-impregnated specimens were heated at different heating steps versus the permeability value measured at ambient conditions (Table 1 and Table 2).

Table 1: Correlation between the gas permeability of un-impregnated specimens at ambient conditions (unheated) with different stages of heat-treatment in different species.

\begin{tabular}{|c|c|c|c|c|c|}
\hline Species (ambient) & $\begin{array}{l}\text { Heated } \\
\left(50^{\circ} \mathbf{C}\right)\end{array}$ & $\begin{array}{l}\text { Heated } \\
\left(75^{\circ} \mathrm{C}\right)\end{array}$ & $\begin{array}{l}\text { Heated } \\
\left(100^{\circ} \mathrm{C}\right)\end{array}$ & $\begin{array}{l}\text { Heated } \\
\left(125^{\circ} \mathrm{C}\right)\end{array}$ & $\begin{array}{l}\text { Heated } \\
\left(150^{\circ} \mathbf{C}\right)\end{array}$ \\
\hline Beech & $0,644 * *(+)$ & $0,628 * *(+)$ & $0,688 * *(+)$ & $0,658 * *(+)$ & $0,486 *(+)$ \\
\hline Poplar (sapwood) & $0,662 * *(+)$ & $0,667 * *(+)$ & $0,777 * *(+)$ & $0,668 * *(+)$ & $0,722 * *(+)$ \\
\hline Poplar (heartwood) & $0,945 * *(+)$ & $0,938 * *(+)$ & $0,924 * *(+)$ & $0,926 * *(+)$ & $0,913 * *(+)$ \\
\hline Fir & $0,897 * *(+)$ & $0,786^{* *}(+)$ & $0,813 * *(+)$ & $0,673 * *(+)$ & $0,627 * *(+)$ \\
\hline \multicolumn{6}{|c|}{$\begin{array}{l}\text { ** Correlation is significant at the } 1 \% \text { level (2-tailed) } \\
\qquad(+) \text { Positive correlation }\end{array}$} \\
\hline
\end{tabular}

Table 2: Correlation analysis between the gas permeability of nanosilver-impregnated specimens at ambient conditions with different stages of nanosilver-impregnation and heat-treatment in different species.

\begin{tabular}{|c|c|c|c|c|c|c|}
\hline Species (ambient) & $\begin{array}{l}\text { Nanosilver } \\
\text { Impregnation }\end{array}$ & $\begin{array}{l}\text { Heated } \\
\left(50^{\circ} \mathrm{C}\right)\end{array}$ & $\begin{array}{l}\text { Heated } \\
\left(75^{\circ} \mathrm{C}\right)\end{array}$ & $\begin{array}{l}\text { Heated } \\
\left(100^{\circ} \mathrm{C}\right)\end{array}$ & $\begin{array}{l}\text { Heated } \\
\left(125^{\circ} \mathrm{C}\right)\end{array}$ & $\begin{array}{l}\text { Heated } \\
\left(150^{\circ} \mathrm{C}\right)\end{array}$ \\
\hline Beech & $0,850 * *(+)$ & $0,646 * *(+)$ & $0,659 * *(+)$ & $0,702 * *(+)$ & $0,729 * *(+)$ & $0,559 * *(+)$ \\
\hline Poplar (sapwood) & $0,859 * *(+)$ & $0,816 * *(+)$ & $0,817 * *(+)$ & $0,831 * *(+)$ & $0,808 * *(+)$ & $0,843 * *(+)$ \\
\hline Poplar (heartwood) & $0,633 * *(+)$ & $0,856 * *(+)$ & $0,862 * *(+)$ & $0,850 * *(+)$ & $0,839^{* *}(+)$ & $0,805 * *(+)$ \\
\hline Fir & $0,714 * *(+)$ & $0,831 * *(+)$ & $0,831 * *(+)$ & $0,818 * *(+)$ & $0,794 * *(+)$ & $0,833 * *(+)$ \\
\hline \multicolumn{7}{|c|}{$\begin{array}{l}\text { ** Correlation is significant at the } 1 \% \text { level (2-tailed) } \\
\qquad(+) \text { Positive correlation }\end{array}$} \\
\hline
\end{tabular}

The highest R-square values were found in poplar heartwood. The trends in poplar heartwood showed a rather constant value and no particular fluctuation observed as the temperature increased from 50 to $150^{\circ} \mathrm{C}$; this can imply that heat-treatment up to $150^{\circ} \mathrm{C}$ cannot significantly affect permeability in poplar heartwood and therefore high R-square was observed. 
Surface plots of un-impregnated and nanosilver-impregnated of different sizes and species versus the heat-treatment steps showed a steady increase in permeability values as the temperature increased (Figure 3a, Figure 3b). Only at higher temperatures of about 125 and $150^{\circ} \mathrm{C}$ were some inconsistencies observed. The fluctuations in permeability values that occurred at the higher temperatures in Figure 1a, Figure 1b, Figure 1c, Figure 1d) caused the inconsistencies against the normal trend. High and statistically significant R-squares that were found by fitted-line plots also approve that in small size specimens, heat treatment at temperatures up to $150^{\circ} \mathrm{C}$ cannot significantly affect the permeability values (Figure 4a, Figure 4b).

a. Surface Plot of Temperature vs Beech-B18; Beech-B18-NS

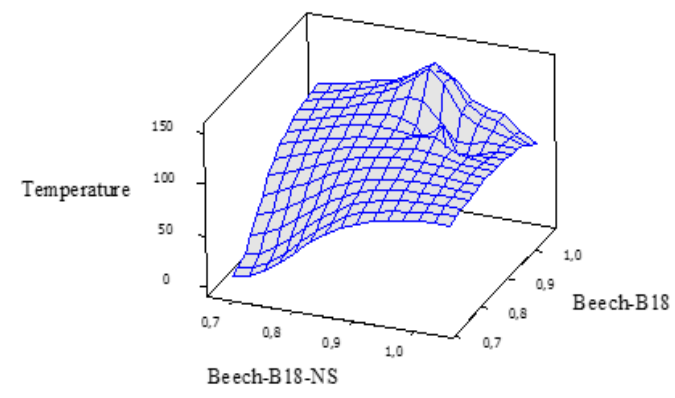

b. Surface Plot of Temperature vs Fir-B18; Fir-B18-NS

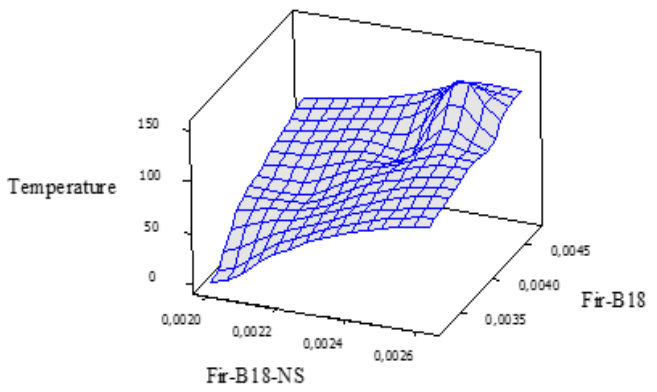

Figure 3: Surface plots of un-impregnated and nanosilver-impregnated (a) beech and (b) fir specimens size 18 .

( $\mathrm{B}=$ beech; $\mathrm{N}=$ nanosilver-impregnated). 

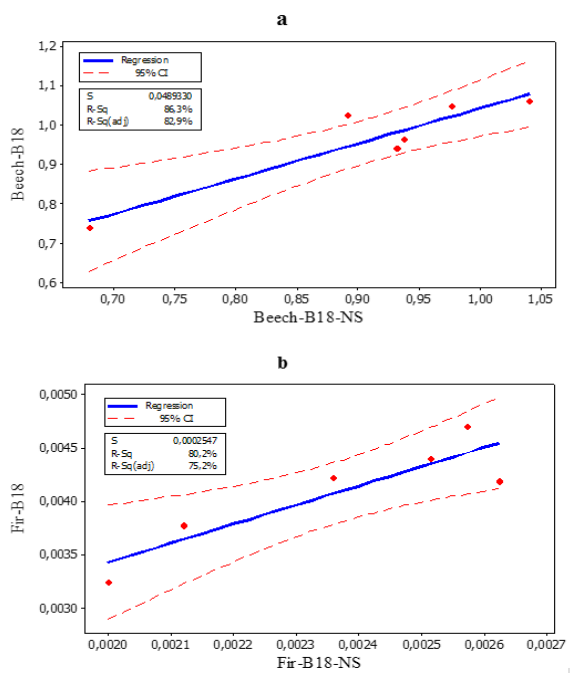

Figure 4: Fitted-line plots of un-impregnated and nanosilver-impregnated beech (a) and fir (b) specimens size 18 .

( $\mathrm{B}=$ beech; $\mathrm{N}=$ nanosilver-impregnated).

\section{CONCLUSIONS}

High variance in specific gas permeability values exists in specimens cut from the same position of tree. This can be attributed to high fluctuation of extract settlement at different location spots of a tree.

In small size specimens, specific gas permeability values are not dependant on the diameter of specimens.

Loss of moisture content can significantly increase permeability.

Thermal degradation up to $150^{\circ} \mathrm{C}$ does not significantly affect specific gas permeability in beech, poplar, and fir wood.

\section{ACKNOWLEDGMENTS}

The author appreciates the kind cooperation of Engr. Younes Sarvari Samadi (specialized in porous media and fluid flow) for his great help in analyzing the results, and the kind support of Alexander von Humbolt Stiftung, Germany.

\section{REFERENCES}

Avramidis, S.; Mansfield, S.D. 2005. On Physical Properties of six Aspen Clones. Holzforschung 59(1): 54-58.

Ayata, U.; Akcay, C.; Esteves, B. 2017. Determination of decay resistance against Pleurotus ostreatus and Coniophora puteana fungus of heat-treated Scotch pine, oak and beech wood species. Maderas-Cienc Tecnol 19(3): 309-316.

Esmailpour, A.; Taghiyari, H.R.; Zolfaghari, H. 2017. Effects of heat treatment on sound absorption coefficients in nanosilver-impregnated and normal solid woods. IET Nanobiotechnology 11(4): 365-369.

Figueroa, M.; Bustos, C.; Dechent, P.; Reyes, L.; Cloutier, A.; Giuliano, M. 2012. Analysis of rheological and thermo-hygro-mechanical behaviour of stress-laminated timber bridge deck in variable environmental conditions. Maderas-Cienc Tecnol 14(3): 303-319. 
Ghorbani, M.; Akhtari, M.; Taghiyari, H.R.; Kalantari, A. 2012. Effects of silver and zincoxide nanoparticles on gas and liquid permeability of heat-treated Paulownia wood. Austrian J Forest Sci 129(1): 106-123.

Hill, C. 2006. Wood Modification Chemical, Thermal and Other Processes. John Wiley \& Sons, Ltd., ISBN: 0-470-02172-1; pp 239.

Imamura, H. 1989. Contribution of extractives to wood characteristics. In: Rowe JW (eds) Natural Products of Woody Plants. Springer Series in Wood Science. Springer, Berlin, Heidelberg. pp $843-860$.

Ismita, N.; Lokesh, C. 2017. Effects of different nanoclay loadings on the physical and mechanical properties of Melia composite particle board. Bois et Forets des Tropiques 334(4): 7-12.

Majidi, R. 2016. Electronic properties of graphyne nanotubes filled with small fullerenes: A density functional theory study. Journal of Computational Electronics 15(4): 1263-1268.

Matinise, N.; Fuku, X.; Maaza, M. 2016. Fabrication of Mixed Phase Bimetallic Zinc Cobaltite Nanocomposite via Moringa Oleifera Green Synthesis. Journal of Nanomaterial \& Molecular Nanotechnology 5:6.

Muñoz, F.; Moya, R. 2018. Effect of nanoclay-treated UF resin on the physical and mechanical properties of plywood manufactured with wood from tropical fast growth plantations. Maderas-Cienc Tecnol 20(1): 11-24.

Papadopoulos, A. 2012. Sorption of acetylated pine wood decayed by brown rot, white rot, and soft rot: different fungi - different behavior. Wood Sci Technol 46(5): 919 - 926.

Pethig, R. 2017. Review - Where is dielectrophoresis (DEP) going? Journal of the Electrochemical Society 164(5): B3049 - B3055.

Poonia, P.K.; Hom, S.K.; Sihag, K.; Tripathi, S. 2016. Effect of microwave treatment on longitudinal air permeability and preservative uptake characteristics of chir pine wood. Maderas-Cienc Tecnol 18(1): 125-132.

Salman, S.; Thevenon, M.F.; Petrissans, A.; Dumarcay, S.; Candelier, K.; Gerardin, P. 2017. Improvement of the durability of heat-treated wood against termites. Maderas- Cienc Tecnol 19(3): 317-328.

Shi, S.H.Q. 2007. Diffusion model based on Fick's second law for the moisture absorption process in wood fiber-based composites: is it suitable or not? Wood Sci Technol 41(8): 645-658.

Siau, J.F. 1995. Wood: Influence of Moisture on Physical Properties. Blacksburg, VA, Department of Wood Science and Forest Products Virginian Polytechnic Institute and State University, 1-63.

Suganya, S.; Kumar, P.S.; Saravanan, A. 2017. Construction of active bio-nanocomposite by inseminated metal nanoparticles onto activated carbon: probing to antimicrobial activity. IET Nanobiotechnology 11(6): 746-753.

Taghiyari, H.R.; Karimi, A.N.; Parsapajouh, D.; Pourtahmasi, K. 2010. Study on the longitudinal gas permeability of juvenile wood and mature wood. Special Topics \& Reviews in Porous Media 1(1): 31-38.

Taghiyari, H.R.; Layeghi, M.; Aminzadeh-Liyafooee, F. 2012. Effects of dry ice on gas permeability of nano-silver-impregnated Populus nigra and Fagus orientalis. IET Nanobiotechnology 6(2): 40-44.

Taghiyari, H.R.; Mobini, K.; Sarvari-Samadi, Y.; Doosti, Z.; Karimi, F.; Asghari, M.; Jahangiri, A.; Nouri, P. 2013. Effects of nano-wollastonite on thermal conductivity coefficient of medium-density fiberboard. Journal of Nanomaterials \& Molecular Nanotechnology 2:1 